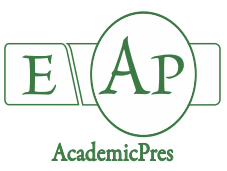

Hossain R et al. $(2020)$
Notulae Botanicae Horti Agrobotanici Cluj-Napoca
DOI:10.15835/nbha48311986
Research Article

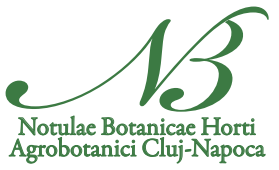

\title{
Pharmacological and ADMET-based pharmacokinetic properties of Syzygium samarangense var. parviflorum leaf extract in in vitro, in vivo and in silico models
}

\author{
Rahni HOSSAIN ${ }^{1}$, Md. A. RAHMAN ${ }^{2 *}$, Md. K. J. RAFI' ${ }^{2}$, \\ Tanvir A. SIDDIQUE ${ }^{2}$, Abdullah A. NOMAN ${ }^{1}$, Arwa MAKKI ${ }^{3}$, \\ Walla ALELWANI ${ }^{3}$, Dina HAJJAR ${ }^{3}$, Jitbanjong TANGPONG ${ }^{4}$
}

\author{
${ }^{1}$ International Islamic University, Department of Pharmacy, Chittagong, Kumira, Chittagong-4318, Bangladesh; \\ rehnihossain@gmail.com; aanoman60@gmail.com \\ ${ }^{2}$ University of Chittagong, Department of Biochemistry \& Molecular Biology, Chittagong-4331, \\ Bangladesh; atiar@cu.ac.bd (*correspondingauthor);krafi.cu@gmail.com; tanvir03.cu@gmail.com \\ ${ }^{3}$ University of Jeddah, Faculty of Science, Department of Biochemistry, Jeddah 80203, Saudi Arabi; dhajjar@uj.edu.sa; \\ amaki@uj.edu.sa; welwani@uj.edu.sa \\ ${ }^{4}$ Walailak University, School of Allied Health Sciences, Biomedical Sciences Program, Nakhon Si Thammarat, 80160, \\ Thailand; rjitbanj@wu.ac.th
}

\begin{abstract}
This research investigated pharmacological properties mainly the anti-inflammatory, anthelmintic, thrombolytic and anxiolytic potential of methanol extract of Syzygium samarangense (MESS) var. parviflorum. Anti-inflammatory action by bovine serum albumin, egg albumin denaturation and membrane stabilization, anthelmintic by live parasites, thrombolytic by clot lysis and anxiolytic by elevated plus maze (EPM) and light and dark box (LDB) tests were measured. The four targeted pharmacological properties were further justified using the most prevalent compounds, isolated from this plant, to be undergone for their pharmacokinetic property's analyses, sitemap analyses and lignad-receptor interactions by computational models through SwissADME and Schrödinger, 2018 softwares against PDB 6COX, 6D6T, 1JFF receptors. MESS was found to display statistically significant $(\mathrm{P}<$ $0.05)$ inhibition of Bovine Serum albumin and Egg albumin denaturation compared to reference drug diclofenac sodium. Remarkable vermicidal effect on the paralysis and death of anthelmintic parasites was observed at MESS concentration $200 \mathrm{mg} / \mathrm{dL}$. A nondescript clot lysis of MESS compared to streptokinase was evident in in vitro thrombolytic assay. MESS increased the number of times the animal crossed from one compartment to the other and the time spent in the brightly-lit chamber of the LDB. Three-methylchalcone derivatives out of seven MESS compounds were undertaken, based on cut off value and sitemap prediction score, for further ligand-receptor binding efficiency. All these three compounds showed promising docking score, glide emodel and glide energy against PDB 6COX, 6D6T and 1DDJ, plasmin proteins demonstrating the prospects of MESS to be materialized for anti-inflammatory, anthelmintic, and thrombolytic therapeutics with further clarification.
\end{abstract}

Keywords: anthelmintic; anti-inflammatory; anxiolytic; Syzygium samarangense, thrombolytic 
Abbreviations: Bw: Body weight; BSA-Bovine Serum Albumin; CNS-Central Nervous System; EPMElevated Plus Maze; GABA-Gama Amino Butyric Acid; MESS: Methanolic extract of Syzygium samarangense; NSAID: Non-Steroidal Anti-inflammatory Drugs; PBS-Phosphate Buffer Solution

\section{Introduction}

Natural products revealed so far have played a dynamic role, due to their safety and efficacy, in improving human health despite facing a tough competition from compounds resulting from computational and combinatorial chemistry. To date 35,000-70,000 plant species have been screened for their medicinal uses to cure different diseases (Veeresham, 2012). In recent years, there has been a renewal in the use of traditional medicinal plants due to their more affordability, less side effects, higher effectiveness and patient's compliance (Calixto, 2000). Therefore, pharmaceutical companies are spending a lot of money in evolving plant-based drugs (Abdel-Hameed et al., 2014). The beneficial effects of medicinal plants generally result from the mixtures of secondary metabolites which are capable of producing definite physiological action (Lekhak et al., 2009).

Syzygium samarangense (Myrtaceae) is a tropical tree distributed throughout Bangladesh, Philippines, India, Indonesia and Malaysia, Vietnam, Taiwan, Thailand where it is known as Jamrul, Wax-apple, Water apple, Malay apple, Java apple, Makopa, Jambu klampok, Jambu air mawar, Chomphu-khieo (Khandaker et al., 2015). All of its parts have potential medicinal applications. The root is used as an antipyretic and a diuretic (Kuo et al., 2004). S. samarangense bark is reported to be effective as analgesic, anti-inflammatory and other CNS activities (Mollika et al., 2013). Four flavonoids isolated from the hexane extract of $S$. samarangenseleaves showed dose-dependent spasmolytic activity in rabbit (Ghayur et al., 2006). Its fruit have cytotoxic chalcones and antioxidants activity (Simirgiotis et al., 2008). Syzygium samarangense affects glycogenesis and glycolysis pathways in tumor necrosis factor- $\alpha$-Treated FL83B mouse hepatocytes (Shen et al., 2013) and alcoholinduced liver injury in mice model (Zhang et al., 2016). A compound named vescalagin, isolated from fruits of S. samarangense, showed hypoglycemic activity (Shen et al., 2013). Myrtaceae plants have been reported as potential sources of dietary polyphenolic antioxidants compounds (Neergheen et al., 2006) anti-inflammatory in mice model (Muruganandan et al., 2001), antibacterial (Bhuiyan et al., 1996), anti-HIV activity (Kusumoto et al., 1995). The plant exerts medicinal herbs for the treatment of bronchitis, asthma, diabetic mellitus and inflammation syndromes in mice model (Gurib-Fakim, 1991). Syzygium samarangense has bioactivities of triterpenes and a sterol from (Raga et al., 2011) prolyl endopeptidase inhibitors (Amor et al., 2004). Its fruits have antiproliferative, apoptotic activities against human lung cancer cell and leaves have analgesic, antiinflammatory (carrageenan induced paw edema test) and CNS activity in mice model (Mollika et al., 2014). From the leaves of $S$. samarangense, two antihyperglycemic flavonoids have been reported, namely, $2^{\prime}, 4^{\prime}$ dihydroxy-3',5'-dimethyl-6'- methoxychalcone, and its isomeric flavone, 5-O-methyl-4'-desmethyl matteucci in diabetic induced mice model (Resurreccion-Magno et al., 2005). Immunomodulatory effects have also been described for a number of flavonoids isolated from the acetone extract of the leaves of the plant, as demonstrated through their inhibitory potency on human peripheral blood mononuclear cell proliferation activated by phytohemagglutinin (Simirgiotis et al., 2008). This research estimated in vitro anti-inflammatory, anthelmintic, thrombolytic and in vivo anxiolytic activity of methanol extract from $S$. samarangense (MESS) leaves. The studied in vitro and in vivo pharmacological actions were further verified by a ligand-receptor interaction through in silico analyses of the most prevalent three compounds 2' 4 '-dihydroxy-6'methoxy-3',5'dimethylchalcone, 2'-hydroxy-4',6'-dimethoxy-3'-methylchalcone, and 2',4'-dihydroxy-6'-methoxy-3'methylchalcone (Ragasa et al., 2014) isolated from this plant. 


\section{Materials and Methods}

\section{Plant materials}

The leaves of Syzygium samarangense var. parviflorum were collected from local area of Chittagong, Bangladesh during April 2019. A sample of $S$. samarangense was identified by the taxonomist and Professor Dr. Sheikh Bokhtear Uddin of the Department of Botany, University of Chittagong, Bangladesh. A voucher specimen of the identification has been deposited in the institutional Herbarium with the accession number MPSS2019/01.

\section{Chemicals}

All chemicals and reagents were of analytical grade. Methanol, chloroform, sulphuric acid, hydrochloric acid, Tween 80, aspirin, streptokinase (1500000 IU) were purchased from Popular Pharmaceuticals Ltd. Bangladesh, bovine serum albumin (Sigma-Aldrich, USA), and Diclofenac sodium (Sigma-Aldrich, USA) was also procured from local supplier. Ferric chloride, potassium ferricyanide, sodium hydroxide and sodium nitrite were purchased from Riedel-De Haen Ag, Seelze-Hannover-Germany. Diazepam and albendazole were also bought from Square Pharmaceuticals Ltd.

\section{Maintenance of experimental animal}

Forty-eight Swiss albino mice of 6-7 weeks old of both sexes $(n=40)$ were collected from the Department of Pharmacy, Jahangirnagar University, Savar, Bangladesh. The average weights of the mice were 20-25 g. Based on average weight, the animals were randomly divided into four groups namely: Normal control, Standard Control, MESS200 and MESS400. They were individually housed in polycarbonated cages filled with wood husk. Optimum environmental conditions were maintained to rear the mice. The conditions were 12-hours light/dark cycle, 55-65\% relative humidity, and $24.0 \pm 2.0^{\circ} \mathrm{C}$ temperatures. Also, the mice were supplied with ample pellet diet ad libitum and drinking water. Animal care and handling of this research project was quite controlled under the institutional animal ethical protocols (AERB/FBS/UC/01,2019) which also covered the collection of blood sample from human. In all experiments using animals, an inhalational anesthetic, isoflurane, was used to alleviate animal pain, and they were euthanized by cervical dislocation after completing experiments.

\section{Preparation of plant extract}

The collected leaves were dried and ground (Orpat blender) into powder (40 to $80 \mathrm{mesh}, 500 \mathrm{~g}$ ) and soaked for 7 days with 2 to 3 days interval in $2.0 \mathrm{~L}$ of methanol at room temperature $\left(23 \pm 0.5^{\circ} \mathrm{C}\right)$. Filtrate obtained through sterile cotton and Whatman filter paper No. 1 was concentrated under reduced pressure at a temperature below $50^{\circ} \mathrm{C}$ using a rotary evaporator (Bibby Scientific RE300). The extracts were all placed in glass petri dishes. A $100 \mathrm{mg}$ of the extract was suspended in $10 \mathrm{ml}$ distilled water and the suspension was shaken vigorously by using a vortex mixer. In this way, the concentration of methanol extracts was prepared for screening the anti-inflammatory, anthelmintic, thrombolytic and anxiolytic properties.

\section{Acute toxicity study}

Five animals maintained in laboratory conditions were used for acute toxicity study. Five animals received a single oral dose of $0.5,1.0,1.5$, and $2.0 \mathrm{~g} / \mathrm{kg} \mathrm{b.w.} \mathrm{of} \mathrm{MESS.} \mathrm{Animals} \mathrm{were} \mathrm{kept} \mathrm{over-night} \mathrm{fasting} \mathrm{prior}$ to administration of MESS. After administration, food was withheld for further 3 to $4 \mathrm{~h}$. Individual animal was kept in close observation during the first $30 \mathrm{~min}$ after dosing, periodically first $24 \mathrm{~h}$ (special attention for the first $4 \mathrm{~h}$ ), thereafter for a period of 3 days to record the delayed toxicity. Once daily cage side observation including changes in skin and fur, eyes and mucous membrane, respiratory and circulatory rate, autonomic and CNS changes were observed. The effective therapeutic dose was taken as one tenth of the median lethal dose $\left(\mathrm{LD}_{50}>2.0 \mathrm{~g} / \mathrm{kg}\right)($ Zaoui et al., 2002). 


\section{In vitro anti-inflammatory activity}

Inhibition of protein denaturation using bovine serum albumin (BSA)

Anti-inflammatory activity of MESS was observed by using bovine serum albumin according to the methods introduced by (Mizushima and Kobayashi, 1968) with minor modifications. Briefly, the experiment was carried out in triplicate pairs (per dose). The reaction mixture $(0.5 \mathrm{~mL})$ contained $0.45 \mathrm{ml} \mathrm{BSA}(5 \%$ aqueous solution) and $0.05 \mathrm{~mL}$ of different concentrations $(31.25,62.5,125,250,500$ and $1000 \mu \mathrm{g} / \mathrm{mL}) \mathrm{of}$ MESS and diclofenac sodium $(0.05 \mathrm{~mL})$ for standard sample instead of MESS at same concentrations. Each solution was attuned to $\mathrm{pH} 6.3$ by $1 \mathrm{~N} \mathrm{HCl}$. The samples were incubated at $37^{\circ} \mathrm{C}$ for $20 \mathrm{~min}$ and heated at 57 ${ }^{\circ} \mathrm{C}$ for $30 \mathrm{~min}$. After cooling phosphate buffer $(2.5 \mathrm{ml})$ was added and absorbance was measured at $416 \mathrm{~nm}$ via spectrophotometer. For test control $0.05 \mathrm{~mL}$ distilled water was used with $0.45 \mathrm{~mL}$ of BSA. The control represents $100 \%$ protein denaturation. The percentage inhibition of protein denaturation was deliberated by following formula:

Percentage inhibition of protein denaturation $=\frac{\text { Absorbance of control }- \text { Aborbance of test sample }}{\text { Absorbance of control }} \times 100$

\section{Inhibition of protein denaturation using egg albumin}

Anti-inflammatory activity of MESS was examined by using egg albumin followed (Mizushima and Kobayashi, 1968; Gupta et al., 2015) methods. The experiment was carried out in triplicate pairs (per dose). The reaction mixture $(5 \mathrm{~mL})$ comprised $0.2 \mathrm{~mL}$ egg albumin with $2.8 \mathrm{~mL}$ of PBS and $2 \mathrm{~mL}$ of different concentrations $(31.25,62.5,125,250,500$ and $1000 \mu \mathrm{g} / \mathrm{mL})$ of MESS. For the standard sample the mixture $(5 \mathrm{~mL}$ ) contained $0.2 \mathrm{~mL}$ of egg albumin with $2.8 \mathrm{~mL}$ of PBS and $2 \mathrm{~mL}$ same concentration of diclofenac sodium. The samples were incubated at $37^{\circ} \mathrm{C}$ for $15 \mathrm{~min}$ and heated at $70{ }^{\circ} \mathrm{C}$ for $15 \mathrm{~min}$ in regulated water bath. The resulting solution was cooled down to room temperature and the turbidity of the solution was measured spectrophotometrically at $660 \mathrm{~nm}$. The control solution $(5 \mathrm{~mL})$ contains $0.2 \mathrm{~mL}$ of egg albumin and $2 \mathrm{ml}$ of distilled water and $2.8 \mathrm{~mL}$ of phosphate buffered saline (PBS). The percentage inhibition of protein denaturation was calculated using the following formula:

Percentage inhibition of protein denaturation $=$ (Absorbance of control Absorbance of test sample)/(Absorbance of control) $\times 100$

\section{Human red blood cell stabilization method}

Membrane stabilization method was performed as previous method (Vane and Botting, 1995) with slight modifications. Blood $(5 \mathrm{~mL})$ was collected from healthy human volunteers who had not taken any NSAIDs for prior to the experiment. Then mixed with equivalent volume of sterilized Alsever's solution (2\% dextrose, $0.8 \%$ sodium citrate, $0.5 \%$ citric acid and $0.42 \%$ sodium chloride in water) and centrifuged at 3000 $\mathrm{rpm}$. The packed cells were washed with isosaline and $10 \% \mathrm{v} / \mathrm{v}$ suspension of red blood cells was prepared and used for study. Test solution consisted of $1 \mathrm{~mL}$ of phosphate buffer ( $\mathrm{pH} 7.4,0.15 \mathrm{M})$, hypotonic saline ( $2 \mathrm{~mL})$, $0.5 \mathrm{~mL}$ of MESS and aspirin (for standard solution) at various concentrations $(31.25,62.5,125,250,500$ and $1000 \mu \mathrm{g} / \mathrm{mL})$, respectively and 10\% HRBC $(0.5 \mathrm{ml})$. Test control solution comprised phosphate buffer $(1 \mathrm{~mL}$ 1), distilled water $(2 \mathrm{~mL})$ and $10 \% \mathrm{HRBC}(0.5 \mathrm{~mL})$ in isotonic saline. Assay mixtures were incubated at $37^{\circ} \mathrm{C}$ for $30 \mathrm{~min}$, centrifuged at $3000 \mathrm{rpm}$ for $20 \mathrm{~min}$, the supernatant was emptied and hemoglobin content was estimated at $560 \mathrm{~nm}$ spectrophotometrically. Percentage of hemolysis was estimated by assuming the hemolysis produced in the control as $100 \%$. The percentage of hemolysis was projected using following formula:

Percentage of hemolysis $=\frac{\text { Absorbance of test sample }}{\text { Absorbance of control }} \times 100$

\section{In vitro anthelmintic activity}

Anthelmintic activity of MESS was investigated by using the method of (Qureshi and Bhatti, 2008; Ali et al., 2012) through clean mature earthworms. Live parasite named Lumbricus terrestris (Nematoda) were collected from soil. Test samples of the aqueous MESS were arranged at concentrations of 200, 100, 50 and 25 
$\mathrm{mg} / \mathrm{mL}$ in normal saline. Three earthworms of each just almost same size were positioned in test tubes containing $(25-200 \mathrm{mg} / \mathrm{mL})$ of the MESS for trial solution. Albendazole $(15 \mathrm{mg} / \mathrm{mL})$ and tween-80 $(0.2 \%)$ containing three test worms were used as standard and negative control respectively. The paralysis and death time ( $\mathrm{min})$ were noted. When all movement had stopped it was defined as paralysis and when no movement occurred it was defined as death upon shaking or placing the worms into warm water $\left(50^{\circ} \mathrm{C}\right)$.

\section{In vitro thrombolytic activity}

Thrombolytic activity of MESS was carried as reported earlier (Alam et al., 2015) with some changes. Blood $(3 \mathrm{~mL})$ was collected from healthy volunteers $(\mathrm{n}=10$, excluding females from the experiment). From these $(0.5 \mathrm{~mL} /$ tube $)$ transferred to each three previously weighed microcentrifuge tubes to form clots and incubated at $37^{\circ} \mathrm{C}$ for $45 \mathrm{~min}$. After clot formation, serum was completely removed without disturbing the clot and each tube having clot was again weighed to determine the clot weight (clot weight $=$ weight of clot containing tube- weight of tube alone). Each tube contains pre-weighed clot and $0.1 \mathrm{~mL}$ of MESS for test solution, streptokinase as positive control and distilled water as negative control were used to separately added and incubated at $37^{\circ} \mathrm{C}$ for $90 \mathrm{~min}$ and observed for clot lysis. After incubation, fluid released was removed and tubes were again weighed to observe the difference in weight after clot disruption. Change in weight before and after clot lysis was expressed as percentage of clot lysis as shown below:

Percentage of clot lysis $=\frac{\text { Weight of released clot }}{\text { Clot weight }} \times 100$

\section{In vivo anxiolytic activity}

Elevated plus maze (EPM) test

The elevated plus maze test was performed by the published protocol (Lister, 1987). The EPM apparatus is a plus sign figure and consists of two open arms $(5 \times 10 \mathrm{~cm})$ and two closed arms $(5 \times 15 \mathrm{~cm})$ radiating from a platform $(5 \times 5 \mathrm{~cm})$. The apparatus was situated on $40 \mathrm{~cm}$ upstairs of the floor. The open arms boundaries were $0.5 \mathrm{~cm}$ in height to keep the mice from falling and the closed arms boundaries were $15 \mathrm{~cm}$ in height (Ferdousy et al., 2017). Sixty minutes after administration of the test extract and drugs, each animal was placed at the center of the maze facing one of the bound arms. Through a $5 \mathrm{~min}$ test period, the number of open and bounded arms entries and the time spent in open and enclosed arms was recorded. Entry into an arm was defined as the point when the animal places all four paws onto the arm. The maze was wiped clean with 10\% ethanol and dried after each trial and the method was conducted in a sound diminished room.

\section{Light and dark box (LDB) test}

The light and dark box test was completed as described protocol (Ambavade et al., 2006). The box having a size of $30 \times 20 \times 14 \mathrm{~cm}$ with a fixed partition in ' the middle. A hole of $3 \mathrm{~cm}$ diameter was made at a height of $7.5 \mathrm{~cm}$ in the center of the cage (Yadav et al., 2008; Ferdousy et al., 2017). The box has one open light chamber and one closed dark chamber with wooden top. 60 min after administration of solution (MESS200, MESS400), negative control and positive control (diazepam) treated mice were positioned in one chamber for crossing the whole to another and $5 \mathrm{~min}$ test period was counted the number of crossing one chamber from another, time spent in lighted box (sec), time spent in dark box (sec) and duration of immobility (sec).

\section{Statistical analysis}

The data were analyzed by one-way ANOVA followed by Dunnet's test to estimate significant differences between the test and control groups with GraphPad Prism Data Editor for Windows, version 5.0 (GraphPad Software Inc, San Diego, CA, USA). Values were expressed as mean \pm standard error of the mean (SEM). 


\section{In silico study pharmacokinetic profile by Swissadme}

SwissADME an online tool (http://www.swissadme.ch/) were used to determine the pharmacokinetic parameters or drug-likeness properties of the selected compounds. The drugs which are administrated orally should follow the Lipinski rule of five (Lipinski et al., 1997) to describe the pharmaceutical fidelity i.e. molecular weight of the compounds, lipophilicity $(\log P)$, the number of hydrogen bond acceptors, the number of hydrogen-bond donors. The canonical smiles of the compounds from PubChem database were used to perform the study.

\section{In silico molecular docking analysis}

Apparatus used for docking

Schrödinger Suites 2018-4 was used to study the molecular docking. The steps involved in docking described below:

\section{Ligand preparation}

The ligand preparation was carried by LigPrep (2018) that produced 3D structures with correct chiralities for all the imported structures (Schrödinger, 2018). To study conformational energy of the system a default force field (OPLS_2005) was applied (Madhavi Sastry et al., 2013). Epik version 4.6.12 was used to yield possible tautomeric and ionization states at target $\mathrm{pH}$ of $7.0 \pm 2.0$ applying Hammett and Taft equations (Shelley et al., 2007). Stereochemical isomers were generated by retaining specific chiralities using stereoizer. Finally, the optimized structures were stored as Maestro format. Streptokinase (CID-9815560), 2'4'dihydroxy-6'methoxy-3',5'-dimethylchalcone (CID-10424762), 2'-hydroxy-4',6'-dimethoxy-3'methylchalcone (CID-72974780), 2',4'-dihydroxy-6'-methoxy-3'-methylchalcone (CID-73097563), diclofenac sodium (CID-5018304), diazepam (CID-3016), albendazole (CID-2082) were reclaimed from PubChem in SDF format.

\section{Protein preparation}

The X-ray crystallographic structures of PDB IDs 1DDJ, 6COX, 6D6T, 1JFF were taken from RCSB Protein Data Bank (PDB). As the structures of proteins were not suitable for molecular modeling that found from PDB, protein preparation wizard was used to modify the structures (Schrödinger, 2018). By using Glide version 8.1.12 this tool used protein from its raw state (missing hydrogen atoms, incorrect order assignments, orientation and charge states) to properly optimized state and made it suitable (Olsson et al., 2011). The protein structures were imported and a series of methods including assigned unshaped bond orders using CCD database, added circumstantial hydrogens, creates zero order bonds to metals, created disulfides bonds, filled in the missing side chains, filled in missing loops using Prime from Schrödinger Release 2018-4: Prime 5.4.12, Schrödinger, LLC, New York, NY, 2018, deleted waters that are beyond $5.00 \AA$ from het groups, generated probable ionization and tautomeric het states using Epik at $\mathrm{pH} 7.0 \pm 2.0$. The subsequent stage involved $\mathrm{H}$ bond optimization followed by orienting sample water molecules, amide groups of asparginine (ASN) and glutamine (GLN) and the imidazole ring in histidine (HIS), hydroxyl and thiol groups Protein Preparatin wizard 2018-4; Epik version 4.6.12, Schrödinger, LLC, 2018-4 and PROPKA was used at the specified pH by Schrödinger Release 2018-4: SiteMap, Schrödinger, LLC, 2018-4for determining of protonation states and predicting of pKa values of the protein residues(Søndergaard et al., 2011; Schrödinger, 2018) . After the revision of hydrogen bonding network waters were removed which had less than $3 \mathrm{H}$-bons to non-waters. Finally, the restrained minimization purged the structure by converging heavy atoms to RMSD of $0.30 \AA$.

\section{Sitemap: prediction of active sites}

The proteins reclaimed from the databases of PDB 6COX, 6D6T, 1JFF had multiple binding sites and 1DDJ had no versed binding sites for interacting ligand with protein receptor. SiteMap from Schrödinger, 2018-4, employed to find out the probable binding sites (Nayal and Honig, 2006) and potential allosteric 
binding sites that if respective proteins were possibly bind with ligand compactly (Halgren, 2007). SiteMap analysis visualized portion on or close to the protein surface that compatible for ligand-receptor binding. Maps were produced turning on hydrophobic and hydrophilic (donor, acceptor and metal binding portions) maps. SiteScore and druggability score (Dscore) including parameters of site size, volume, exposure, enclosure, contact, hydrophobic and hydrophilic character, balance (phobic/philic ratio) and donor/acceptor of hydrogen bond were used for verification of each active site (Halgren, 2009), hence separating the sites of binding. Potent sites in co-crystallized complexes discriminated drug binding and non- drug binding sites followed by Sitescore. Dscore differentiated druggable targets from undruggable with the help of Glide, v8.1.12, Schrödinger, LLC, 2018-4.

\section{Receptor grid generation}

SiteMap were used to visualize binding sites that describe receptor and the potential active site was picked as the entry. Glide, v8.1.12, Schrödinger, LLC, 2018-4, looked for suitable interaction among a ligand and a protein (Schrödinger, 2018). To soften the potential for non-polar part of the receptors, Van der Waals radii of receptor atoms with partial charge (absolute value) scaled at default setting of scaling factor 1.0 and partial charge cutoff 0.25 . For grid generation and others parameters like site, constraints, rotatable groups, and excluded volumes were set to default setting as provided by Maestro 11.8.

\section{Glide ligand molecular docking}

By completing all the preparative assignments, the ligands and the protein were compatible for docking. Van der Waals radii for non-polar parts of the ligands were fixed at scaling factor 0.80 and partial charge cutoff 0.15 . The precision was set up at SP (Standard precision) for ligand screening of known quality and ligand sampling were flexible for docking. In conformer generation energy window was set up at $2.5 \mathrm{kcal} / \mathrm{mol}$ for sampling the ring. Initial poses were kept 5000 poses per ligand and scoring window was 100 and 400 for best poses per ligand to minimize the energy. Post docking minimization for 5 numbers of poses per ligand was performed. Threshold was $4.00 \mathrm{kcal} / \mathrm{mol}$ for strain correction and scaling factor was 0.25 for excess strain energy. The rest parameters were remaining at default (Friesner et al., 2004; Halgren et al., 2004; Friesner et al., 2006).

\section{Results}

\section{Acute toxicity status}

The sample MESS was found to be nontoxic in acute toxicity test. No abnormality or organoleptic change of the experimental animal was observed after administration of MESS.

\section{In vitro anti-inflammatory activity}

Inhibition of protein denaturation using bovine serum albumin (BSA)

The MESS was found nontoxic in acute toxicity test. Anti-inflammatory activity was performed by using Bovine serum albumin. The minimum percentage inhibition of protein denaturation by MESS was observed as $36.02 \pm 2.56 \%$ for $31.25 \mu \mathrm{g} / \mathrm{mL}$ and $71.59 \pm 2.01 \%$ for standard drug diclofenac sodium at the same dose. The results are summarized in Table 1 .

Inhibition of protein denaturation using egg albumin

In vitro anti-inflammatory activity by Egg albumin denaturation method at concentration of 31.25 $\mu \mathrm{g} / \mathrm{mL}$ MESS extract showed $22.85 \pm 1.37 \%$ at minimum percentage whereas diclofenac sodium showed 74.44 $\pm 2.11 \%$ at the same dose (Table 2). 
Human red blood cell stabilization method

All the doses of MESS $(31.25,62.5,125,250,500$ and $1000 \mu \mathrm{g} / \mathrm{mL})$ showed a significant inhibition against inhibition of hemolysis of RBCs (Table 3). Within different concentrations, minimum inhibition of hemolysis $23.47 \pm 1.51 \%$ was observed $31.25 \mu \mathrm{g} / \mathrm{mL}$ of MESS and $79.15 \pm 1.33 \%$ for the same dose of standard NSAID aspirin.

Table 1. Percentage inhibition of bovine serum albumin denaturation by diclofenac sodium and MESS at different concentration

\begin{tabular}{|c|c|c|}
\hline \multicolumn{2}{|c|}{ Percent inhibition of protein denaturation } \\
\hline $\begin{array}{c}\text { Concentration } \\
(\mu \mathrm{g} / \mathrm{mL})\end{array}$ & $\begin{array}{c}\text { MESS } \\
\text { Mean } \pm \text { SEM }\end{array}$ & $\begin{array}{c}\text { Diclofenac sodium } \\
\text { Mean } \pm \text { SEM }\end{array}$ \\
\hline 31.25 & $36.02 \pm 2.56^{\mathrm{a}}$ & $71.59 \pm 2.01^{\mathrm{b}}$ \\
\hline 62.5 & $43.87 \pm 1.70^{\mathrm{a}}$ & $77.60 \pm 1.12^{\mathrm{b}}$ \\
\hline 125 & $47.44 \pm 1.27^{\mathrm{a}}$ & $81.46 \pm 1.47^{\mathrm{b}}$ \\
\hline 250 & $51.10 \pm 1.38^{\mathrm{a}}$ & $83.90 \pm 1.13^{\mathrm{b}}$ \\
\hline 500 & $57.18 \pm 1.14^{\mathrm{a}}$ & $88.02 \pm 2.29^{\mathrm{b}}$ \\
\hline 1000 & $60.21 \pm 0.99^{\mathrm{a}}$ & $93.76 \pm 2.56^{\mathrm{b}}$ \\
\hline
\end{tabular}

Values are expressed as Mean \pm SEM of three replicate $(n=3)$. Data were analyzed by one-way ANOVA followed by Dunnet's test to estimate significant differences between the test and reference control with GraphPad Prism Data Editor for Windows, version 5.0. Values were considered significant at $\mathrm{P}<0.05$.

Table 2. Percentage inhibition of egg albumin denaturation by diclofenac sodium and MESS at different concentration

\begin{tabular}{|c|c|c|}
\hline \multicolumn{2}{|c|}{ Percent inhibition of protein denaturation } \\
\hline $\begin{array}{c}\text { Concentration } \\
(\mu \mathrm{g} / \mathrm{mL})\end{array}$ & $\begin{array}{c}\text { MESS } \\
\text { Mean } \pm \text { SEM }\end{array}$ & $\begin{array}{c}\text { Diclofenac sodium } \\
\text { Mean } \pm \text { SEM }\end{array}$ \\
\hline 31.25 & $22.85 \pm 1.37^{\mathrm{a}}$ & $74.44 \pm 2.11^{\mathrm{b}}$ \\
\hline 62.5 & $28.87 \pm 1.58^{\mathrm{a}}$ & $82.32 \pm 2.12^{\mathrm{b}}$ \\
\hline 125 & $39.95 \pm 2.30^{\mathrm{a}}$ & $85.06 \pm 2.57^{\mathrm{b}}$ \\
\hline 250 & $45.69 \pm 2.88^{\mathrm{a}}$ & $90.08 \pm 0.72^{\mathrm{b}}$ \\
\hline 500 & $52.80 \pm 2.77^{\mathrm{a}}$ & $94.86 \pm 1.25^{\mathrm{b}}$ \\
\hline 1000 & $58.22 \pm 2.22^{\mathrm{a}}$ & $96.46 \pm 0.55^{\mathrm{b}}$ \\
\hline
\end{tabular}

Values are expressed as Mean \pm SEM of three replicate $(n=3)$. Data were analyzed by one-way ANOVA followed by Dunnet's test to estimate significant differences between the test and control groups with GraphPad Prism Data Editor for Windows, version 5.0. Values were considered significant at $\mathrm{P}<0.05$. 
Table 3. Percentage inhibition of hemolysis by human red blood cell stabilization by aspirin and MESS at different concentrations

\begin{tabular}{|c|c|c|}
\hline \multicolumn{2}{|c|}{ Percent inhibition of hemolysis } \\
\hline $\begin{array}{c}\text { Concentration } \\
(\mu \mathrm{g} / \mathrm{mL})\end{array}$ & $\begin{array}{c}\text { MESS } \\
\text { Mean } \pm \text { SEM }\end{array}$ & $\begin{array}{c}\text { Aspirin } \\
\text { Mean } \pm \text { SEM }\end{array}$ \\
\hline 31.25 & $23.47 \pm 1.51^{\mathrm{a}}$ & $79.15 \pm 1.33^{\mathrm{b}}$ \\
\hline 62.5 & $28.67 \pm 1.27^{\mathrm{a}}$ & $85.79 \pm 1.54^{\mathrm{b}}$ \\
\hline 125 & $35.86 \pm 2.29^{\mathrm{a}}$ & $88.48 \pm 1.52^{\mathrm{b}}$ \\
\hline 250 & $45.21 \pm 2.40^{\mathrm{a}}$ & $92.52 \pm 2.53^{\mathrm{b}}$ \\
\hline 500 & $49.10 \pm 1.20^{\mathrm{a}}$ & $94.04 \pm 1.66^{\mathrm{b}}$ \\
\hline 1000 & $54.80 \pm 2.60^{\mathrm{a}}$ & $96.47 \pm 0.67^{\mathrm{b}}$ \\
\hline
\end{tabular}

Values are expressed as Mean \pm SEM of three replicate $(n=3)$. Data were analyzed by one-way ANOVA followed by Dunnet's test to estimate significant differences between the test and control groups with GraphPad Prism Data Editor for Windows, version 5.0. Values were considered significant at $\mathrm{P}<0.05$.

\section{In vitro anthelmintic activity}

The anthelmintic activity of MESS was compared with standard drug albendazole. Methanol leaves extract at concentrations of $25,50,100$ and $200 \mathrm{mg} / \mathrm{mL}$ showed paralysis of parasites at 15:28, 11:07, 9:18, 5:24 min:sec and death times were found to be 34:47, 30:12, 25:42, 10:30 min:sec, respectively. Standard albendazole also showed paralysis time at 18:46 min:sec and death time at 25:10 min:sec (Table 4).

\section{In vitro thrombolytic activity}

The results of the thrombolytic test are shown in Figure 1. The MESS had a significant clot lysis effect after addition of $100 \mu \mathrm{l} \mathrm{SK}$ (a positive control of 30,000 I.U.) to the clots along with $90 \mathrm{~min}$ of incubation at $37^{\circ} \mathrm{C}$ provided $75.00 \pm 2.60 \%$ clot lysis. On the other hand, sterile distilled water was treated as negative control which showed only $5.55 \pm 1.20 \%$, a negligible clot lysis. Clots when treated with $100 \mu \mathrm{l}$ of MESS exhibited $32.73 \pm 2.57 \%$ clot lysis which is significant $(\mathrm{P}<0.05)$ compared to the positive control.

\section{In vivo anxiolytic activity}

Elevated plus maze (EPM) test

MESS at both doses increased the percentage of entries into the open arm (Figure 2). The percentage of time spent in open arms also increased at the MESS $400 \mathrm{mg} / \mathrm{kg}$ bw and the value was significant $(\mathrm{P}<0.05)$ compared to negative control group. There was also a significant increase in duration of time ( $42 \pm 2.83)$ for MESS400 into open arm which was statistically significant as compared to that $(35.5 \pm 3.54)$ of reference group.

\section{Light and dark box (LDB) test}

In in vivo light and dark box test, the extract showed movements in test animals at both dose levels (200 and 400 $\mathrm{mg} / \mathrm{kg}$ body weight). At MESS $400 \mathrm{mg} / \mathrm{kg}$ b.w., number of crossing the hole and time spent in lighted box $(29.67 \pm$ $2.71)$ and $(230.80 \pm 16.39)$ sec was comparable with standard drug diazepam (28.50 \pm 2.31$)$ and $(254.00 \pm 7.34)$ respectively. In the hole-cross test, MESS exhibited an increase no. of crossing, time spent in lighted and dark box, duration of immobility of the test animals at both dose levels compared to control and reference drug. The results were statistically significant for all doses and followed a dose-dependent response (Figure 3). 
Hossain R et al. (2020). Not Bot Horti Agrobo 48(3):1155-1175

Table 4. Anthelmintic activity of methanolic extract of Syzygium samarangense leaves and Albendazole against Lumbricus terrestris at different concentrations

\begin{tabular}{|c|c|c|c|}
\hline Drug & $\begin{array}{c}\text { Concentration } \\
(\mathrm{mg} / \mathrm{mL})\end{array}$ & $\begin{array}{c}\text { Paralysis time } \\
(\mathrm{min}: \mathrm{sec})\end{array}$ & $\begin{array}{c}\text { Death time } \\
(\mathrm{min}: \mathrm{sec})\end{array}$ \\
\hline Albendazole & 15 & $18: 46$ & $34: 47$ \\
\hline MESS & 25 & $15: 28$ & $30: 12$ \\
\hline MESS & 50 & $9: 18$ & $25: 42$ \\
\hline MESS & 100 & $5: 24^{*}$ & $10: 30^{*}$ \\
\hline MESS & 200 & None & None \\
\hline Distill water & None & & 5 \\
\hline
\end{tabular}

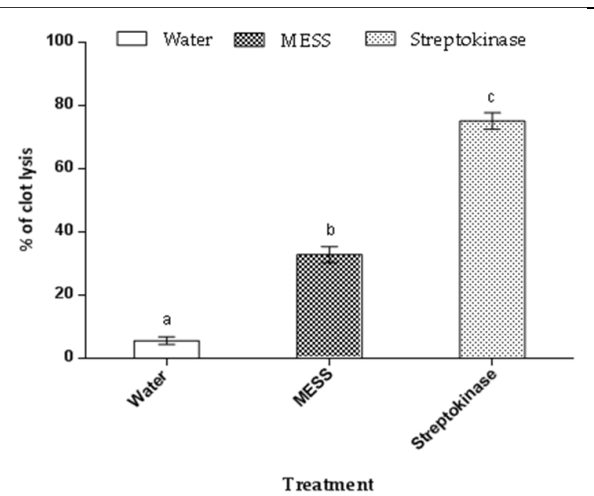

Figure 1. Clot lysis by water and $S$. samarangense methanolic extract compared with streptokinase Values are presented as mean \pm SEM. Data are analyzed by one-way analysis of variance (ANOVA) followed by Dunnet's test to estimate significant differences between the test and control groups with GraphPad Prism Data Editor for Windows, version 5.0 (GraphPad Software Inc, San Diego, CA, USA). Superscript letters (abc) on bar graph are significantly different from each other at experimental condition

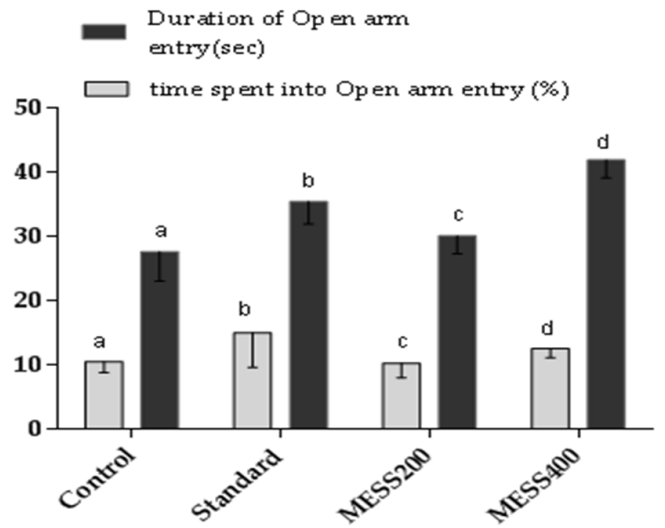

Figure 2. Anxiolytic activity of MESS on duration of open arm in the elevated plus maze (EPM) test for mice

Values are presented as mean \pm SEM. Data are analyzed by one-way analysis of variance (ANOVA) followed by Dunnet's test to estimate significant differences between the test and control groups with GraphPad Prism Data Editor for Windows, version 5.0 (GraphPad Software Inc, San Diego, CA, USA). Superscript letters (abcd) on bar graph are significantly different from each other at experimental condition 


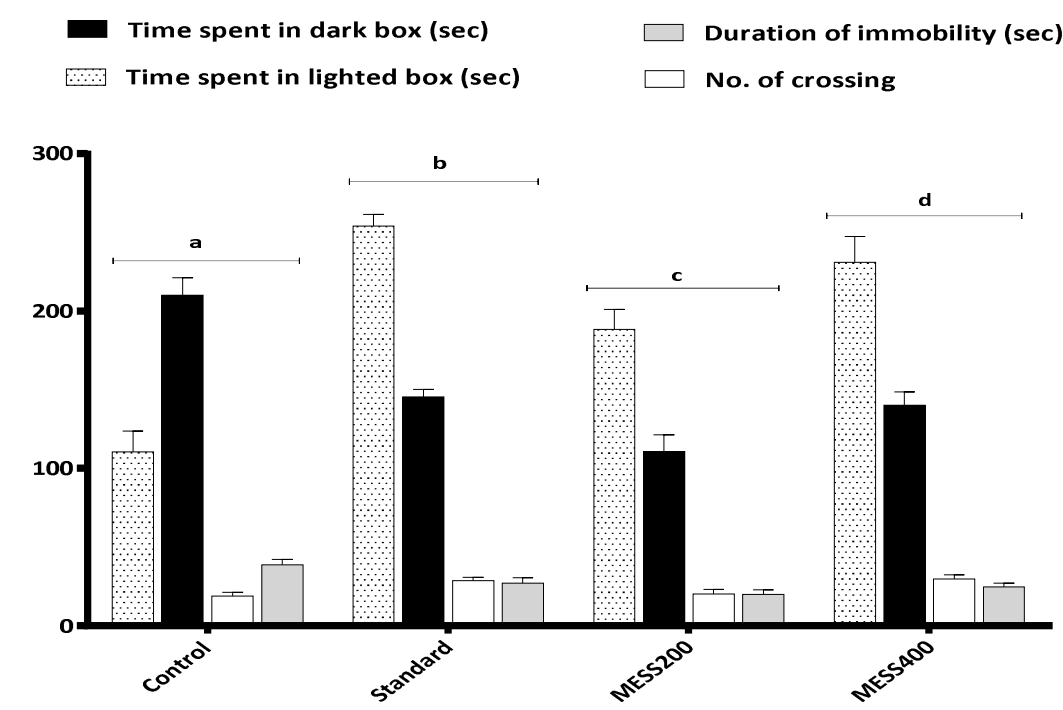

Figure 3. Effects of MESS on anxiolytic activity in light and dark box test for mice

Values are presented as mean \pm SEM. Data are analyzed by one-way analysis of variance (ANOVA) followed by Dunnet's test to estimate significant differences between the test and control groups with GraphPad Prism Data Editor for Windows, version 5.0 (GraphPad Software Inc, San Diego, CA, USA). Superscript letters (abcd) on bar graph are significantly different from each other at experimental condition.

\section{Pharmacokinetic profile}

The pharmacokinetic profile of the compounds (Figure 4) that found in MESS were shown in Table 5 including the parameters molecular weight $(\mathrm{MW})$, rotatable bonds, h-bond donors, h-bond acceptors, lipophilicity $(\log P)$. The results were obtained from the SwissADME databases.

\section{Molecular interaction}

The proteins that were prepared for SiteMap analysis produced various active sites and sites which were produced the best Sitescore and Dscore were chosen for analysis of molecular docking (Table 5). On the basis of site points and hydrophobic part (yellow), hydrogen-bond donor (blue), and hydrogen-bond acceptor (red) maps the graphical feedback is illustrated (Figures 5-8). The site score of 1 and 0.8 describes the prospect and differentiates precisely among the sites of drug binding and non-drug binding respectively. The foundation for designing drug is predicting and understanding the potential active sites on the proteins. The algorithm of sitemap is highly efficient for marking and verifying of binding sites which is very useful for the scientists to accelerate the schemes of the drug discovery that replicates lead optimization and docking also. The phytochemicals namely 2'4'-dihydroxy-6'methoxy-3',5'-dimethylchalcone, 2'-hydroxy-4',6'-dimethoxy-3'methylchalcone, 2',4'-dihydroxy-6'-methoxy-3'-methylchalcone, and reference drugs streptokinase (Thrombolytic), diclofenac sodium (Anti-inflammatory), diazepam (Anxiolytic), albendazole (Anthelmintic) are used for in silico docking study and the comparative analysis were governed by the Glide SP method that enlisted in Table 7 and their particular interaction with proteins are shown in Figures 5-8 along with their mode of binding. 
Table 5. Pharmacokinetic profile of the phytochemicals from the extract of Syzygium samarangense

\begin{tabular}{|c|c|c|c|c|c|}
\hline Compounds & MW & $\begin{array}{c}\text { Rotatable } \\
\text { bonds }\end{array}$ & $\begin{array}{c}\text { H-bond } \\
\text { donor }\end{array}$ & $\begin{array}{c}\text { H-bond } \\
\text { acceptor }\end{array}$ & LogP \\
\hline 2',4'-dihydroxy-6'-methoxy-3'-methylchalcone & 284.31 & 4 & 2 & 4 & 3.01 \\
\hline 2',4'-dihydroxy-6'-methoxy-3',5'-dimethylchalcone & 298.33 & 4 & 2 & 4 & 3.35 \\
\hline 2'-hydroxy-4',6'-dimethoxy-3'-methylchalcone & 314.33 & 5 & 2 & 5 & 2.95 \\
\hline Squalene & 410.72 & 15 & 0 & 0 & 9.38 \\
\hline Betulin & 442.72 & 2 & 2 & 2 & 6.39 \\
\hline Lupeol & 426.72 & 1 & 1 & 1 & 7.31 \\
\hline Sitosterol & 414.71 & 6 & 1 & 1 & 7.19 \\
\hline
\end{tabular}

Table 6. Active site prediction scores of mentioned proteins using SiteMap. Only the top ranked scores are mentioned on the table for each protein

\begin{tabular}{|c|c|c|c|c|c|c|c|c|c|c|c|}
\hline PDB ID & SiteScore & Size & Dscore & Volume & Exposure & Enclosure & Contact & Phobic & Philic & Balance & don/acc \\
\hline 6COX & 1.116 & 109 & 1.15 & 265.482 & 0.37 & 0.82 & 1.074 & 1.302 & 0.864 & 1.507 & 0.857 \\
\hline 1JFF & 1.032 & 90 & 1.041 & 272.685 & 0.492 & 0.789 & 1.012 & 0.781 & 0.996 & 0.784 & 1.132 \\
\hline 1DDJ & 1.06 & 122 & 0.985 & 197.225 & 0.378 & 0.788 & 1.073 & 0.455 & 1.312 & 0.347 & 0.586 \\
\hline 6D6T & 1.132 & 394 & 1.185 & 913.752 & 0.371 & 0.806 & 1.057 & 1.871 & 0.734 & 2.549 & 0.876 \\
\hline
\end{tabular}

Table 7. Binding energy, Glide Emodel and Glide energy among proteins and different ligand compounds measured in $\mathrm{Kcal} / \mathrm{mol}$

\begin{tabular}{|c|c|c|c|}
\hline Compounds & Docking score & Glide emodel & Glide energy \\
\hline \multicolumn{4}{|c|}{ Anti-inflammatory } \\
\hline \multicolumn{4}{|c|}{ 6COX(Cyclooxygenase) } \\
\hline Diclofenac sodium & -7.497 & -43.678 & -31.265 \\
\hline 2'4'-dihydroxy-6'methoxy-3',5'-dimethylchalcone & -5.661 & -17.097 & -18.701 \\
\hline 2'-hydroxy-4',6'-dimethoxy-3'-methylchalcone & -8.639 & -29.8 & -38.439 \\
\hline 2',4'-dihydroxy-6'-methoxy-3'-methylchalcone & -8.274 & -43.038 & -33.722 \\
\hline \multicolumn{4}{|c|}{ Anthelmintic } \\
\hline \multicolumn{4}{|c|}{ 1JFF(Tubulin) } \\
\hline Albendazole & -7.02 & -84.745 & -56.653 \\
\hline 2'4'-dihydroxy-6'methoxy-3',5'-dimethylchalcone & -8.41 & -102.895 & -49.243 \\
\hline 2'-hydroxy-4',6'-dimethoxy-3'-methylchalcone & -6.241 & -67.603 & -48.91 \\
\hline 2',4'-dihydroxy-6'-methoxy-3'-methylchalcone & -8.049 & -106.537 & -53.143 \\
\hline \multicolumn{4}{|c|}{ Thrombolytic } \\
\hline \multicolumn{4}{|c|}{ 1DDJ (Plasmin) } \\
\hline Streptokinase & -6.164 & -38.041 & -27.115 \\
\hline 2'4'-dihydroxy-6'methoxy-3',5'-dimethylchalcone & -5.406 & -36.093 & -32.555 \\
\hline 2'-hydroxy-4',6'-dimethoxy-3'-methylchalcone & -6.751 & -39.707 & -37.914 \\
\hline 2',4'-dihydroxy-6'-methoxy-3'-methylchalcone & -5.383 & -44.16 & -37.329 \\
\hline \multicolumn{4}{|c|}{ Anxiolytic } \\
\hline \multicolumn{4}{|c|}{ 6D6T(GABA) } \\
\hline Diazepam & -5.106 & -32.129 & -24.528 \\
\hline 2'4'-dihydroxy-6'methoxy-3',5'-dimethylchalcone & -5.439 & -42.474 & -36.481 \\
\hline 2'-hydroxy-4',6'-dimethoxy-3'-methylchalcone & -5.106 & -32.129 & -24.528 \\
\hline 2',4'-dihydroxy-6'-methoxy-3'-methylchalcone & -5.503 & -44.845 & -37.466 \\
\hline
\end{tabular}



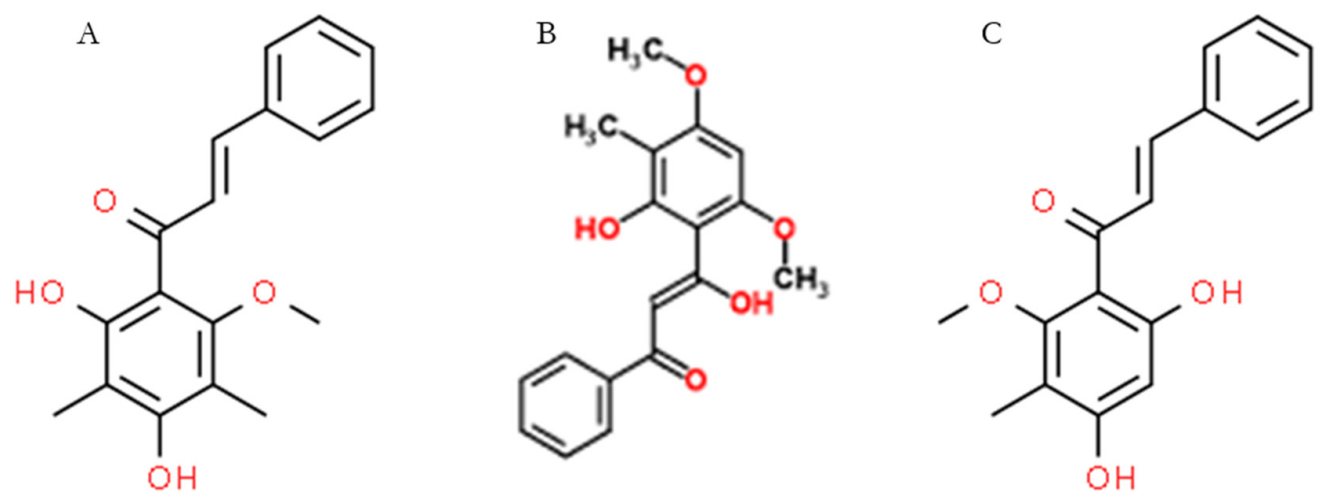

Figure 4. Chemical structures of the three compounds isolated and selected for the docking study

Their compounds are: A) 2'4'-dihydroxy-6'methoxy-3',5'-dimethylchalcone; B) 2'-hydroxy-4',6'-dimethoxy-3'methylchalcone; and C) 2',4'-dihydroxy-6'-methoxy-3'-methylchalcone
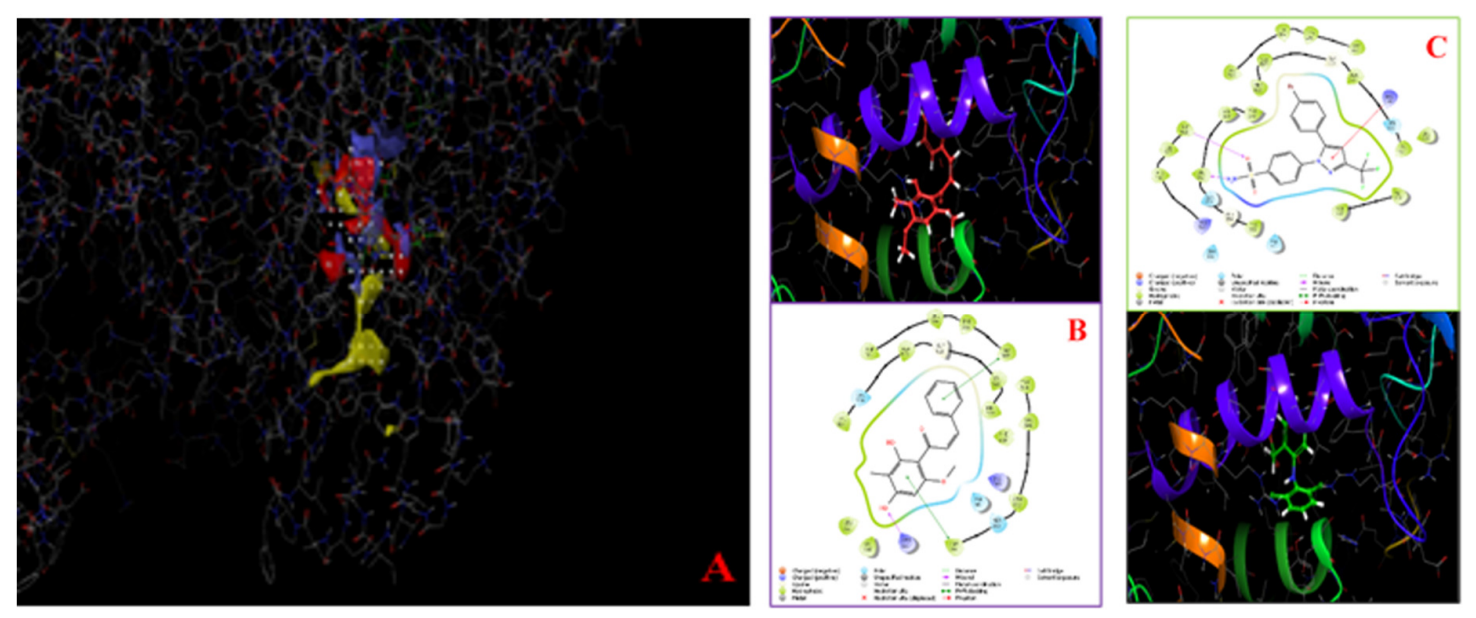

Figure 5. Ligand-receptor (6COX, Cyclooxygenase) interactions showed that (interactions based on site map, A) 2'-hydroxy-4',6'-dimethoxy-3'-methylchalcone (B) showed the highest docking score (-8.639) compared with the reference anti-inflammatory drug diclofenac sodium $(\mathrm{C})$. The $3 \mathrm{D}$ protein binding has been presented with respective amino acid grooves for ligand interaction. The interacted groups are denoted with following color and signs

Charged (negative)

Charged (positive)

Glycine

Hydrophobic

Polar

Water

$\rightarrow \quad$ H-bond

Metal

$\times \quad$ Hydration site (displaced)

$\longrightarrow$ Pi-Pi stackin 

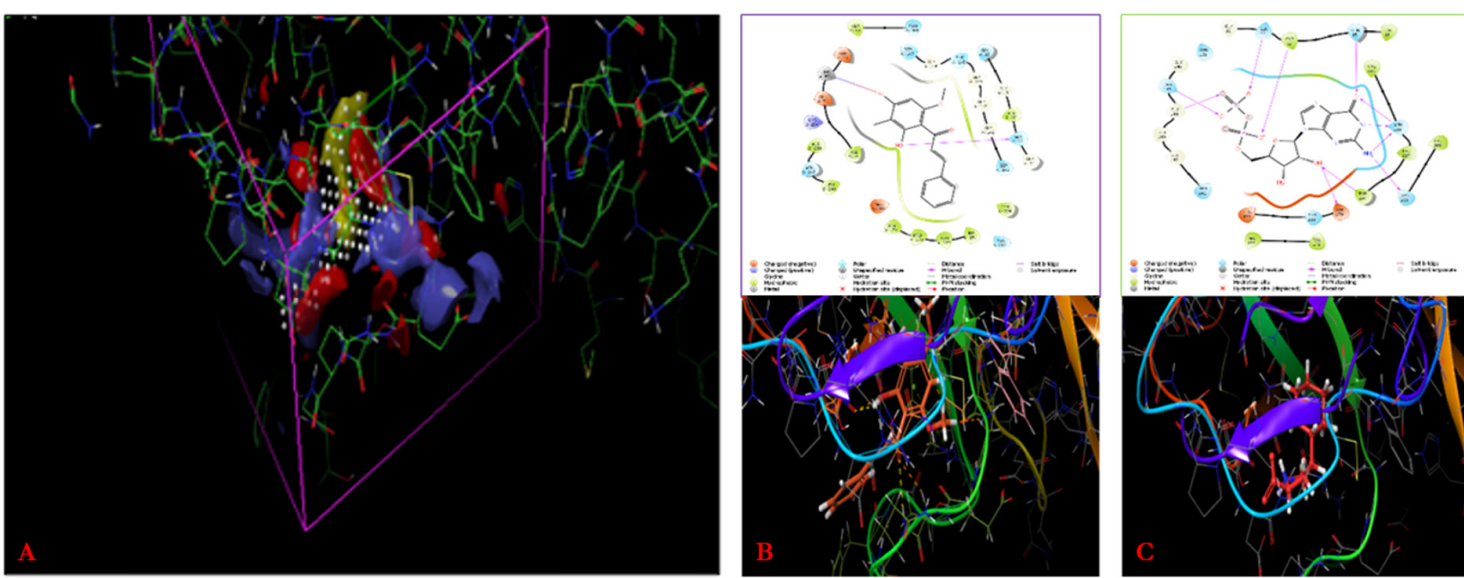

Figure 6. Ligand-receptor (1JFF, Tubulin) interactions showed that (interactions based on site map, A) 2',4'-dihydroxy-6'-methoxy-3'-methylchalcone (B) showed the highest (showed with arrow sign) docking score (-8.049) compared with the reference anti-inflammatory drug albendazole (C). The 3D protein binding has been presented with respective amino acid grooves for ligand interaction. The interacted groups are denoted with following color and signs
Charged (negative)
Charged (positive)
Polar
Polar
Glycine
Hydrophobic
Water
Hydration site
Hydration site (displaced)
$\rightarrow$ Distance
Metal coordination Pi-Pi stacking
Metal
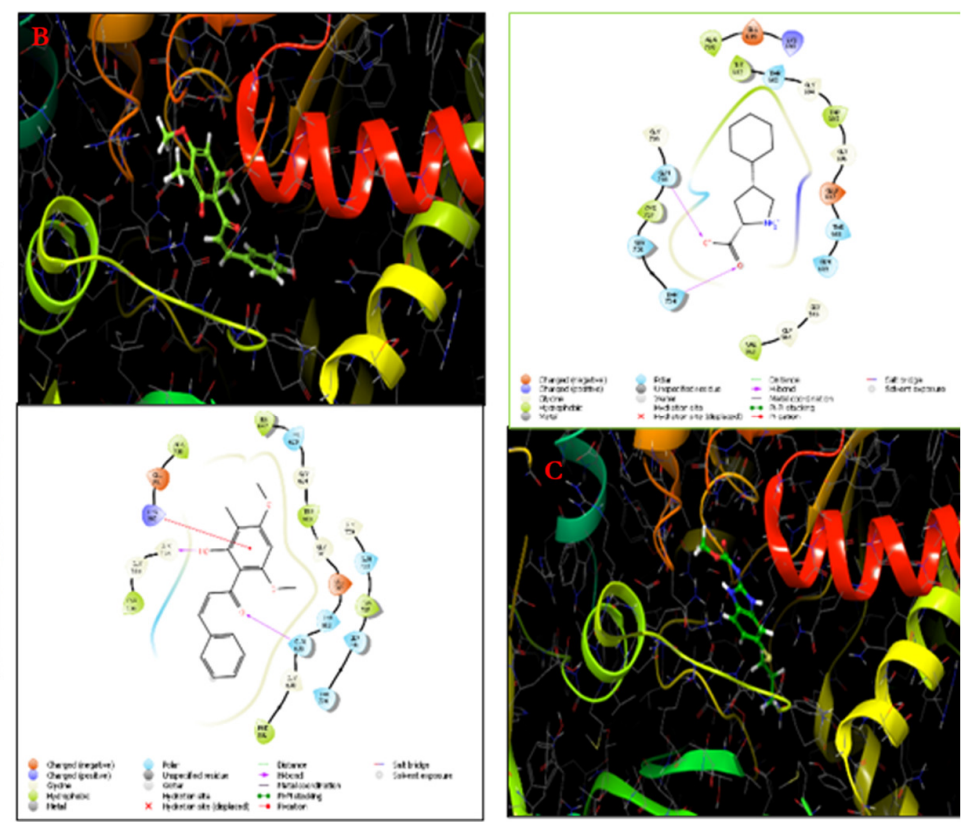

Figure 7. Ligand-receptor (1DDJ, Plasmin) interactions showed that (interactions based on site map, A) 2'-hydroxy-4',6'-dimethoxy-3'-methylchalcone showed the highest (B) docking score (-6.751) compared with the reference anti-inflammatory drug streptokinase $\mathrm{C}$. The $3 \mathrm{D}$ protein binding has been presented with respective amino acid grooves for ligand interaction. The interacted groups are denoted with following color and signs

Charged (negative)

Charged (positive)

Gly cine

Hydrophobic

Metal
Polar

Unspecified residue

Water

Hydration site

Hydration site (displaced)

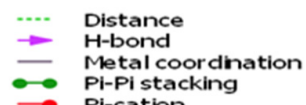

$\mathrm{Pi}-\mathrm{Pi}$ stacking
Pi-cation

$\longrightarrow$ Pi-cation
Salt bridge
Solvent exposur 


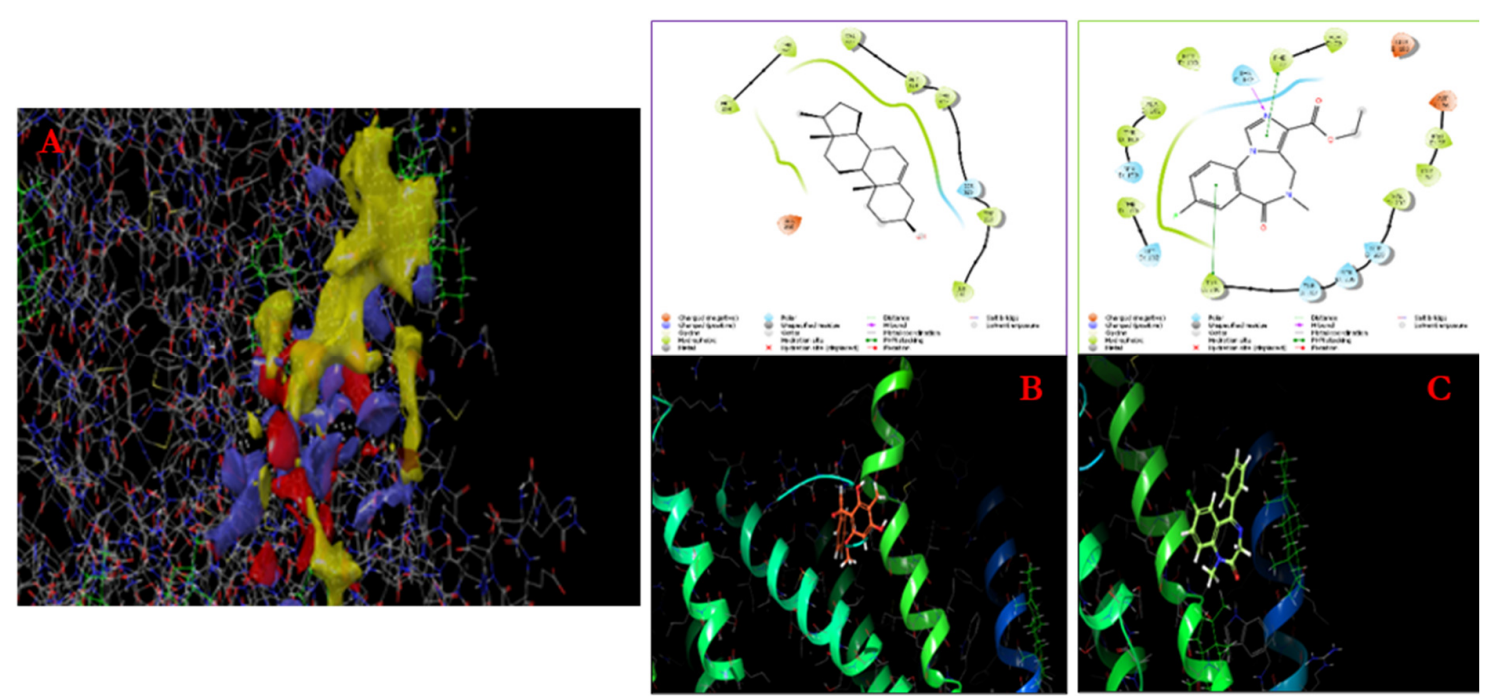

Figure 8. Ligand-receptor (6D6T, GABA) interactions showed that (interactions based on site map A). 2',4'-dihydroxy-6'-methoxy-3'-methylchalcone (B) showed the highest docking score (-5.503) compared with the reference anti-inflammatory drug Diazepam (C). The 3D protein binding has been presented with respective amino acid grooves for ligand interaction. The interacted groups are denoted with following color and signs Charged (negative) Charged (positive) Gly cine Hydrophobic Metal
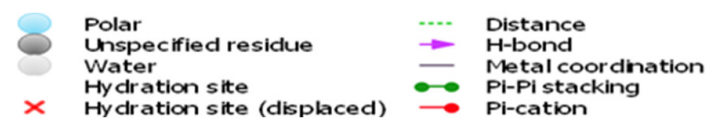

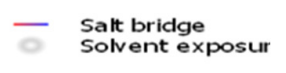

Salt bridge
Solvent exposur pi-cation

\section{Discussion}

Phytochemical investigations indicated that terpenoids, phenols, resins, glycosides, tannins, flavonoids, saponins, alkaloids were present in the MESS (Kuo et al., 2004). These phyto-constituents work with nutrients and fibers to form a combined part of protection system against different diseases and stress circumstances.

Out of several different mechanisms, inhibition of prostaglandin synthesis through cyclooxygenase inhibition is thought to be responsible for anti-inflammatory action of drugs or plant secondary metabolites. In protein denaturation, secondary and tertiary structure of proteins are lost by extrinsic stress, heat, organic solvent or strong acid or base (Yashwant and Aeri, 2013). The mechanism of denaturation comprises variation in electrostatic, hydrogen, hydrophobic and disulfide bonding. In the present investigation, plant extract got a higher inhibitory percentage of protein denaturation which was parallel to diclofenac sodium. The increments in absorbance of test samples with respect to control indicated that MESS has the capability to bring down thermal denaturation of protein (albumin). Since RBC membrane resembles lysosomal membrane so the effect of any agent on HRBC stabilization may be projected to lysosomal membrane stabilization (Uttra and Hasan, 2017). Lysis of lysosomal vesicles and the release of lysosomal content is a key procedure of systemic inflammation elicited by immune cells. These lysosomal enzymes are capable of inducing the inflammatory processes (Bonam, 2019). Substances capable to stabilize the lysosomal membrane structure prevent the membrane rupture and contribute to the anti-inflammatory effects (Chayen and Bitensky, 1971). Thus, a stabilized membrane prevents the progression of inflammation and lowers oxidative damage caused by the free radical generation following inflammation. Traditional NSAID drugs reduce the consequences of inflammation by either stabilizing the membrane or by inhibiting the release of lysosomal contents (Anosike et al., 2012). In fact, the role of NSAIDs in membrane stabilization was postulated before the discovery of their 
role in Cox pathway (Mizushima, 1964). In our study we have found a dose dependent relationship of MESS against aspirin.

In anthelmintic test for the activity, plant extract was normally investigated on the basis of paralysis and death of live parasites. The extract exposed concentration dependent paralysis and death time, which were compared with albendazole $(15 \mathrm{mg} / \mathrm{mL})$. The mechanism of anthelmintic activity of extract is unknown but polyphenolic compounds may play a major part. From phytochemical screening we found that tannins were present in the extract. Tannins may serve anthelmintic activity, chemically tannins are poly phenolic compounds. Thrombus (blood clot) established in the circulatory system due to failure of hemostasis sources vascular blockage and indications to serious significances in thrombotic disorders like acute myocardial or cerebral infarction that may reason death (Sherwani et al., 2013). The contrast between positive and negative controls clearly showed that there was no clot dissolution when water was added to the clot. The increase in clot lysis by MESS compared to the controls determines its potential use in clot-related disorders. Several studies supports that plant extract possesses tannin, alkaloid, and saponin content should have thrombolytic activity (Ghosh et al., 2015). The extract producing a significant dose dependent prolongation of cumulative time spent in the open arms and number of movements of the EPM and Light and dark box, Hole-cross, compared with the control, suggests that MESS causes less fear and less anxiety toward open and elevated area (Yemitan and Adeyemi, 2003) and is comparable to that produced by diazepam, an anti-anxiety drug. In both tests, a dose of $400 \mathrm{mg} / \mathrm{kg}$ of the extract produced very significant results showing that it acts by an inhibitory effect on the central nervous system in a manner, similar to diazepam. The EPM and LDB tests are designed to detect the effect of anxiolytic drugs (Yemitan and Adeyemi, 2003). The anxiolytic, anti-convulsant, musclerelaxant and sedative-hypnotic actions of benzodiazepines makes them the most important GABA modulating drugs (Light et al., 2005) and this may explain the mechanisms of action of MESS as well however, further studies are needed to ascertain this.

ADME analysis of the phytochemicals helped in the selection of the compounds for the docking study. From the seven compounds namely 2'4'-dihydroxy-6'methoxy-3',5'-dimethylchalcone, 2'-hydroxy-4',6'dimethoxy-3'-methylchalcone, 2',4'-dihydroxy-6'-methoxy-3'-methylchalcone, squalene, betulin, lupeol, sitosterol the first three compounds were marked for protein interaction having a $\log P$ value of less than 5 that followed the Lippinski rule of five and the rest were filtered which have a $\log \mathrm{P}$ value of more than 5 . The foundation for designing drug is prediction and understanding the potential active sites on the proteins. The algorithm of sitemap is highly efficient for marking and verifying of binding sites which is very useful for the scientists to accelerate the schemes of the drug discovery that replicates lead optimization and docking also (DiMasi et al., 2003). The phytochemicals namely 2'4'-dihydroxy-6'methoxy-3',5'-dimethylchalcone, 2'hydroxy-4',6'-dimethoxy-3'-methylchalcone, 2',4'-dihydroxy-6'-methoxy-3'-methylchalcone, and reference drugs streptokinase (thrombolytic), diclofenac sodium (anti-inflammatory), diazepam (anxiolytic), albendazole (anthelmintic) are used for in silico docking study and the comparative analysis were governed by the Glide SP mechanism. Proteins that were used highly related with the thrombolytic (PDB ID: 1DDJ) (Wang et al., 2000), anti-inflammatory (PDB ID: 6COX) (Kurumbail et al., 1996), anxiolytic (PDB ID: 6D6T) (Zhu et al., 2018), anthelmintic (PDB ID: 1JFF) (Lowe et al., 2001) activity, therefore used as receptors in molecular docking study. According to this analysis, each of the ligands bond to the receptors had produced particular binding affinity. The docking score glide emodel and glide energy were the parameters to evaluate the ligands. In case of thrombolytic activity $2^{\prime}$-hydroxy-4', $6^{\prime}$-dimethoxy-3'-methylchalcone had a good score compared to others in anti-inflammatory $2^{\prime}, 4^{\prime}$-dihydroxy- $6^{\prime}$-methoxy- $3^{\prime}$-methylchalcone could be ranked first and $2^{\prime}, 4^{\prime}$-dihydroxy-6'-methoxy-3'-methylchalcone could be significant than others in anxiolytic and anthelmintic activity. So, these phytochemicals could be used as inhibitors of thrombocytes formation, inflammation, anxiety and helminths. This type of computational study plays a mentionable role in drug invention and improvement and it can save extensive cost of time and money. 


\section{Conclusions}

Based on the experimental findings of anti-inflammatory, anthelmintic, thrombolytic and anxiolytic activity of methanol extract of $S$. samarangense leaves, it is evident that the plant may contain some novel compounds that possess potent anti-inflammatory, anthelmintic, thrombolytic, anxiolytic activity. The obtained results support that further investigation is required to understand the pharmacological action of antiinflammatory, anthelmintic, thrombolytic and anxiolytic effects. Hence it should be needed to isolate the novel compounds and better to undertake the mechanism of such action of $S$. samarangense. Thus, it can be concluded that the study served its purpose and further investigations should be carried out to isolate and identify more active compounds present in the plant that are responsible for pharmacological activity in the development of novel and safe drugs.

\section{Authors' Contributions}

MAR and RH have designed and planned for research while MAR has endeavored to create a research problem and explored a valid hypothesis for solution. RH along with MKJR, TAS and AAN has carried out the research doing bench work, producing data and analyzing those to infer a solution. RH has also written the manuscript and MAR has made an interpretation of produced data. AAN has done the in-silico study both ADME and molecular docking. MAR, RH, MKJR, TAS checked and went through the manuscript to submit. Arwa Makki, Walla Alelwani and Dina Hajjar have contributed to our research support. JT has contributed in research innovation and funding supports for carrying out the research. All authors read and approved the final manuscript.

Ethical approval (for researches involving animals or humans)

The institutional ethical committee of the Faculty of Biological Sciences of the University of Chittagong has approved the study plan of this research and use of animals and their handling as well as care for this study. The ethical approval number has been allocated as (AERB/FBS/UC/01, 2019).

\section{Acknowledgements}

Authors wish to thank professor Dr. Sheikh Bokhtear Uddin for extending his cooperation to identify the plant and provide the accession number endorsed in Chittagong University Herbarium.

\section{Conflict of Interests}

The authors declare that there are no conflicts of interest related to this article.

\section{References}

Alam MN, Biozid MS, Islam MR, Abedin MJ, Chowdhury S (2015). In-vitro comparative study of cytotoxic and thrombolytic effects of methanolic extract of Cissus pentagona and Thunbergia grandiflora (Roxb.) leaves. Journal of Coastal Life Medicine 3(9):724-727. https://doi.org/10.12980/jclm.3.2015j5-62 
Ali N, Shah SWA, Shah I, Ahmed G, Ghias M, Khan I, Ali W (2012). Anthelmintic and relaxant activities of Verbascum thapsus Mullein. BMC Complementary and Alternative Medicine 12(1):29. https://doi.org/10.1186/14726882-12-29

Ambavade S, Mhetre N, Tate V, Bodhankar S (2006). Pharmacological evaluation of the extracts of Sphaeranthus indicus flowers on anxiolytic activity in mice. Indian Journal of Pharmacology 38(4):254. https://doi.org/10.4103/02537613.27021

Amor EC, Villaseñor IM, Yasin A, Choudhary MI (2004). Prolyl endopeptidase inhibitors from Syzygium samarangense (Blume) Merr. \& LM Perry. Zeitschrift für Naturforschung C 59(1-2):86-92. https://doi.org/10.1515/znc-2004$1-218$

Bonam SR, Wang F, Muller S (2019). Lysosomes as a therapeutic target. Nature Review Drug Discovery 18(12):923-948. https://doi.org/10.1038/s41573-019-0036-1

Anosike CA, Obidoa O, Ezeanyika LU (2012). Membrane stabilization as a mechanism of the anti-inflammatory activity of methanol extract of garden egg (Solanum aethiopicum). DARU Journal of Pharmaceutical Science 20(1):76. https://doi.org/10.1186/2008-2231-20-76

Bhuiyan M, Mia MY, Rashid M (1996). Antibacterial principles of the seeds of Eugenia jambolana. Bangladesh Journal of Botany 25(2):239-241.

Calixto JB (2000). Efficacy, safety, quality control, marketing and regulatory guidelines for herbal medicines (phytotherapeutic agents). Brazilian Journal of Medical and Biological Research. 33(2):179-189. https://doi.org/10.1590/S0100-879X2000000200004

Chayen J, Bitensky L (1971). Lysosomal enzymes and inflammation with particular reference to rheumatoid diseases. Annals of Rheumatic Disease 30(5):522. https://doi.org/10.1136/ard.30.5.522

Dey P, Chaudhuri D, Tamang S, Chaudhuri TK, Mandal N (2012). In vitro antioxidant and free radical scavenging potential of Clerodendrum viscosum. International Journal of Pharmaceutical and Biological Science 3(3):454471.

DiMasi JA, Hansen RW, Grabowski HG (2003). The price of innovation: new estimates of drug development costs. Journal of Health Economics 22(2):151-185. https://doi.org/10.1016/S0167-6296(02)00126-1

Ferdousy S, Rahman MA, Al-Amin MM, Aklima J, Chowdhury JKH (2017). Antioxidative and neuroprotective effects of Leea macrophylla methanol root extracts on diazepam-induced memory impairment in amnesic Wistar albino rat. Clinical Phytoscience 2(1):17. https://doi.org/10.1186/s40816-016-0031-6

Friesner RA, Banks JL, Murphy RB, Halgren TA, Klicic JJ, Mainz DT, ... Shenkin PS (2004). Glide: a new approach for rapid, accurate docking and scoring. 1. Method and assessment of docking accuracy. Journal of Medicinal Chemistry 47(7):1739-1749. https://doi.org/10.1021/jm0306430

Friesner RA, Murphy RB, Repasky MP, Frye LL, Greenwood JR, Halgren TA, ... Mainz DT (2006). Extra precision glide: docking and scoring incorporating a model of hydrophobic enclosure for protein-ligand complexes. Journal of Medicinal Chemistry 49(21):6177-6196. https://doi.org/10.1021/jm051256o

Ghayur M, Gilani A, Khan A, Amor E, Villaseñor I, Choudhary M (2006). Presence of calcium antagonist activity explains the use of Syzygium samarangense in diarrhoea. Phytotherapy Research: An International Journal Devoted to Pharmacological and Toxicological Evaluation of Natural Product Derivatives 20(1):49-52. https://doi.org/10.1002/ptr.1801

Ghosh A, Banik S, Islam MA (2015). In vitro thrombolytic, anthelmintic, anti-oxidant and cytotoxic activity with phytochemical screening of methanolic extract of Xanthium indicum leaves. Bangladesh Journal of Pharmacology 10(4):854-859. https://doi.org/10.3329/bjp.v10i4.23829

Gupta AK, Parasar D, Sagar A, Choudhary V, Chopra BS, Garg R, Khatri N (2015). Analgesic and anti-inflammatory properties of gelsolin in acetic acid induced writhing, tail immersion and carrageenan induced paw edema in mice. PloS One 10(8):e0135558. https://doi.org/10.1371/journal.pone.0135558

Gurib-Fakim A (1991). Phytochemical screening of 38 Mauritian medicinal plants. Revue Agricole et Sucrière de l'lle Maurice 69:42-50.

Halgren T (2007). New Method for fast and accurate binding-site identification and analysis. Chemical Biology \& Drug Design 69(2):146-148. https://doi.org/10.1111/j.1747-0285.2007.00483.x.

Halgren TA (2009). Identifying and characterizing binding sites and assessing druggability. Journal of Chemical Information Modeling 49(2):377-389. https://doi.org/10.1021/ci800324m 
Joshi B, Lekhak S, Sharma A (2009). Antibacterial property of different medicinal plants: Ocimum sanctum, Cinnamomum zeylanicum, Xanthoxylum armatum and Origanum majorana. Kathmandu University Jouranl of Science, Engineering and Technology 5(1):143-150. https://doi.org/10.3126/kuset.v5i1.2854

Khandaker MM, Alebidi A, Hossain AS, Mat N, Boyce AN (2015). Physiological and biochemical properties of three cultivars of wax apple (Syzygium samarangense [Blume] Merrill \& LM Perry) fruits. Journal of Sustainability Science and Management 10(1):66-75.

Kuo YC, Yang LM, Lin LC (2004). Isolation and immunomodulatory effect of flavonoids from Syzygium samarangense. Planta Medica 70(12):1237-1239. https://doi.org/10.1055/s-2004-835859

Kurumbail RG, Stevens AM, Gierse JK, McDonald JJ, Stegeman RA, Pak JY, ... Stallings WC (1996). Structural basis for selective inhibition of cyclooxygenase inflammatory agents. Nature 384:644-648-2. https://doi.org/10.1038/384644aO

Kusumoto IT, Nakabayashi T, Kida H, Miyashiro H, Hattori M, Namba T, Shimotohno K (1995). Screening of various plant extracts used in ayurvedic medicine for inhibitory effects on human immunodeficiency virus type 1 (HIV1) protease. Phytotherapy Research 9(3):180-184. https://doi.org/10.1002/ptr.2650090305

Light M, Sparg S, Stafford G, Van Staden J (2005). Riding the wave: South Africa's contribution to ethnopharmacological research over the last 25 years. Journal of Ethnopharmacology 100(1-2):127-130. https://doi.org/10.1016/j.jep.2005.05.028

Lipinski CA, Lombardo F, Dominy BW, Feeney PJ (1997). Experimental and computational approaches to estimate solubility and permeability in drug discovery and development settings. Advanced Drug Delivery Reviews 23(1):3-25. https://doi.org/10.1016/s0169-409x(00)00129-0

Lister RG (1987). The use of a plus-maze to measure anxiety in the mouse. Psychopharmacology 92(2):180-185. https://doi.org/10.3126/kuset.v5i1.2854

Lowe J, Li H, Downing KH, Nogales E (2001). Refined structure of alpha beta-tubulin at 3.5 A resolution. Journal of Molecular Biology 313:1045-1057. https://doi.org/10.1006/jmbi.2001.5077

Madhavi Sastry G, Adzhigirey M, Day T, Annabhimoju R, Sherman W (2013). Protein and ligand preparation: parameters, protocols, and influence on virtual screening enrichments. Journal of Computer-Aided Molecular Design 27(3):221-234. https://doi.org/10.1007/s10822-013-9644-8

Martin IL (1996). The GABAA/benzodiazepine receptor as a target for psychoactive drugs. Oxford Univ Press https://doi.org/10.2147/NDT

Mizushima Y (1964). Inhibition of protein denaturation by antirheumatic or antiphlogistic agents. Archives Internationales de Pharmacodynamie et de Therapie 149:1-7. https://doi.org/10.1007/BF02976483

Mizushima Y, Kobayashi M (1968). Interaction of anti-inflammatory drugs with serum proteins, especially with some biologically active proteins. Journal of Pharmacy and Pharmacology 20(3):169-173. https://doi.org/10.1111/j.2042-7158.1968.tb09718.x

Mollika S, Islam N, Parvin N, Kabir A, Sayem M, Luthfunnesa SR (2014). Evaluation of analgesic, anti-inflammatory and CNS activities of the methanolic extract of Syzygium samarangense leave. Global Journal of Pharmacology 8(1):39-s46. https://doi.org/10.5829/idosi.gjp.2014.8

Mollika S, Nesa ML, Munira MS, Islam DM, Sayem MW, Parvin N, Nasim M (2013). Evaluation of analgesic, antiinflammatory and CNS activities of the methanolic extract of Syzygium Samarangense bark. IOSR Journal of Pharmacy 3(11):12-18. https://doi.org/10.1016/S0367-326X(00)00325

Muruganandan S, Srinivasan K, Chandra S, Tandan S, Lal J, Raviprakash V (2001). Anti-inflammatory activity of Syzygium cumini bark. Fitoterapia 72(4):369-375. https://doi.org/10.1016/S0367-326X(00)00325

Nayal M, Honig B (2006). On the nature of cavities on protein surfaces: Application to the identification of drug-binding sites. Proteins: Structure, Function, and Bioinformatics, 63(4):892-906. https://doi.org/10.1002/prot.20897

Neergheen VS, Soobrattee MA, Bahorun T, Aruoma OI (2006). Characterization of the phenolic constituents in Mauritian endemic plants as determinants of their antioxidant activities in vitro. Journal of Plant Physiology 163(8):787-799. https://doi.org/10.1016/j.jplph.2005.09.009

Olsson MHM, Søndergaard CR, Rostkowski M, Jensen JH (2011). PROPKA3: Consistent treatment of internal and surface residues in empirical pKa predictions. Journal of Chemical Theory and Computation 7(2):525-537. https://doi.org/10.1021/ct100578z

Qureshi R, Bhatti G (2008). Taxonomy of scrophulariaceae from Nara desert, Pakistan. Pakistan Journal Botany 40(3):973-978. 
Raga DD, Cheng CLC, Lee KCIC, Olaziman WZP, De Guzman VJA and Shen CC (2011). "Bioactivities of triterpenes and a sterol from Syzygium samarangense. Zeitschrift für Naturforschung C 66(5-6):235-244. https://doi.org/10.1515/znc-2011-5-606

Ragasa CY, Franco Jr. FC, Raga DD, Shen CC (2014). Chemical constituents of Syzygium samarangense. Der Pharma Chemica 6(3):256-260.

Resurreccion-Magno MHC, Villaseñor IM, Harada N, Monde K (2005). Antihyperglycaemic flavonoids from Syzygium samarangense (Blume) merr. and perry. Phytotherapy Research: An International Journal Devoted to Pharmacological and Toxicological Evaluation of Natural Product Derivatives 19(3):246-251. https://doi.org/10.1002/ptr.1658

Schrödinger L (2018). New York "Protein Preparation Wizard 2018-4; Epik version 4.6.12, Schrödinger, LLC, New York, NY, 2018; Impact version 8.1.12, Schrödinger, LLC, New York, NY, 2018; Prime 5.4.12, Schrödinger, LLC, New York, NY, 2018".

Schrödinger L (2018) New York. Glide v8.1.12, Schrödinger, LLC, New York, NY, 2018.

Schrödinger L (2018). Schrödinger Release 2018-4: SiteMap, Schrödinger, LLC, New York, NY, 2019. https://doi.org/10.1021/acs.jctc.5b00864

Shelley JC, Cholleti A, Frye LL, Greenwood JR, Timlin MR, Uchimaya M (2007) Epik: a software program for pKa prediction and protonation state generation for drug-like molecules. Journal of Computer-Aided Molecular Design 21(12):681-691. https://doi.org/10.1007/s10822-007-9133-Z

Shen SC, Chang WC, Chang CL (2013). An extract from wax apple (Syzygium samarangense (Blume) Merrill and Perry) effects glycogenesis and glycolysis pathways in tumor necrosis factor- $\alpha$-treated FL83B mouse hepatocytes. Nutrients 5(2):455-467. https://doi.org/10.3390/nu5020455

Sherwani SK, Bashir A, Haider SS, Shah MA (2013). Thrombolytic potential of aqueous and methanolic crude extracts of Camelia sinensis (green tea): in vitro study. Journal of Pharmacognosy and Phytochemistry 2(1):125-129.

Shohayeb M, Abdel-Hameed ESS, Bazaid SA, Maghrabi I (2014). Antibacterial and antifungal activity of Rosa damascena MILL. essential oil, different extracts of rose petals. Global Journal of Pharmacology 8(1):1-7. https://doi.org/10.5829/idosi.gjp.2014.8.1.81275

Simirgiotis MJ, Adachi S, To S, Yang H, Reynertson KA, Basile MJ, ... Kennelly EJ (2008). Cytotoxic chalcones and antioxidants from the fruits of Syzygium samarangense (Wax Jambu). Food Chemistry 107(2):813-819. https://doi.org/10.1016/j.foodchem.2007.08.086

Uttra AM, Hasan UH (2017). Anti-arthritic activity of aqueous-methanolic extract and various fractions of Berberis orthobotrys Bien ex Aitch. BMC Complementary and Alternative Medicine 17(1):371. https://doi.org/10.1186/s12906-017-1879-9

Vane J, Botting R (1995). New insights into the mode of action of anti-inflammatory drugs. Inflammation Reseasrch 44(1):1-10. https://doi.org/10.1007/BF01630479

Veeresham (2012). Natural products derived from plants as a source of drugs. Journal of Advance Pharmaceutical Technology and Research 3(4):200-201. https://doi.org/10.4103/2231-4040.104709

Wang X, Terzyan S, Tang J, Loy JA, Lin X, Zhang XC (2000). Human plasminogen catalytic domain undergoes an unusual conformational change upon activation. Journal of Molecular Biology 295: 903-914. https://doi.org/10.1006/jmbi.1999.3397

Yadav A, Kawale L, Nade V (2008). Effect of Morus alba L.(mulberry) leaves on anxiety in mice. Indian Journal of Pharmacology 40(1):32. https://doi.org/10.4103/0253-7613.40487

Yashwant P, Aeri V (2013). In vitro anti-inflammatory activity of Raupya (Silver) Bhasma. Journal of Chemical and Pharmaceutical Research 5(9):194-197. https://doi.org/10.13140/2.1.1525.0888

Yemitan O, Adeyemi O (2003). Anxiolytic and muscle-relaxant activities of Dalbergia saxatilis. West African Journal of Pharmacological and Drug Research 19(1):42-46. https://doi.org/10.4314/wajpdr.v19i1.14732

Zaoui A, Cherrah Y, Mahassini N, Alaoui K, Amarouch H, Hassar M (2002). Acute and chronic toxicity of Nigella sativa fixed oil. Phytomedicine 9:69-74. https://doi.org/10.1078/0944-7113-00084

Zhang YJ, Zhou T, Wang F, Zhou Y, Li Y, Zhang JJ, ... Li HB (2016). The effects of Syzygium samarangense, Passiflora edulis and Solanum muricatum on alcohol-induced liver injury. International Journal of Molecular Science 17(10):1616. https://doi.org/10.3390/ijms17101616

Zhu S, Noviello CM, Teng J, Walsh RM, Kim JJ, Hibbs RE (2018). Structure of a human synaptic GABAAreceptor. Nature 559:67-72. https://doi.org/10.1038/s41586-018-0255-3 
OPEN ACCESS

(c) (1)

The journal offers free, immediate, and unrestricted access to peer-reviewed research and scholarly work. Users are allowed to read, download, copy, distribute, print, search, or link to the full texts of the articles, or use them for any other lawful purpose, without asking prior permission from the publisher or the author.

License - Articles published in Notulae Botanicae Horti Agrobotanici Cluj-Napoca are Open-Access, distributed under the terms and conditions of the Creative Commons Attribution (CC BY 4.0) License. (C) Articles by the authors; UASVM, Cluj-Napoca, Romania. The journal allows the author(s) to hold the copyright/to retain publishing rights without restriction. 